DOI:10.17951/h.2020.54.1.89-100

\begin{tabular}{lcl}
\hline & A N N A L E S \\
UNIVERSITATIS MARIAE CURIE-SKŁODOWSKA \\
LUBLIN - POLONIA \\
SOL. LIV, 1 & SECTIO H \\
\hline
\end{tabular}

\author{
JERZY WĘCŁAWSKI \\ jerzy.weclawski@poczta.umcs.lublin.pl \\ Maria Curie-Skłodowska University. Faculty of Economics \\ 5 Maria Curie-Skłodowska Sq., 20-031 Lublin \\ ORCID ID: https://orcid.org/0000-0003-0870-5083 \\ HELMUT PERNSTEINER \\ helmut.pernsteiner@jku.at \\ Johannes Kepler University of Linz. Department of Finance \\ Altenberger Straße 69, 4040 Linz \\ ORCID ID: https://orcid.org/0000-0002-3977-6098
}

\title{
The Goals of Polish Family Firms
}

Keywords: family firms; value creation; growth rates; Polish family firms

JEL: D22; D81; L20

How to quote this paper: Węcławski, J., \& Pernsteiner, H. (2020). The Goals of Polish Family Firms. Annales Universitatis Mariae Curie-Skłodowska, sectio H-Oeconomia, Vol. 54, No. 1.

\begin{abstract}
This article investigates the differences in management goals between family owned and non-family owned firms in Poland. The aim is to understand whether there are general differences in between the two types of firms, along with differences in age, the internationalisation grade and the turnover of the firms. We used questionnaire-based interviews (computer-assisted telephone interview (CATI) and computer-assisted web interview (CAWI) techniques) to create a sample of 758 Polish firms that employed more than 49 people. Using the substantial family influence index put forward by Klein (2010, p. 17), we identified 396 firms as being family firms, with the rest being non-family firms. Nine goals were presented to representatives of these firms (owners, chief executive officers (CEOs), chief financial officers (CFOs)) who were then asked to sort them into four groups. The estimation of the empirical data was conducted using descriptive analyses and statistical verifications of the differences in fraction indicators. According to the literature, we found
\end{abstract}


that "independence from others" (control argument) is a significant difference in family firms, along with "long-term value creation" and "high growth rates". Our focus was on Poland, a large, Eastern European country with only a brief history as a market economy. Its private sector is relatively small and there are fewer large and well-established family firms than there are in Western Europe. The practical impact of this study lies in a better understanding of Polish family firms for all stakeholders.

\section{Introduction}

Family firms account for approximately $90 \%$ of all firms in the world (Aldrich $\&$ Cliff, 2003) and they also play the vital role among listed companies. In general terms, this percentage will differ between countries with different economic situations and conditions, particularly if they are more market- or banking-oriented countries. In Poland, approximately $40 \%$ of the total number of firms in the country are family owned (Jeżak, 2016, pp. 52-59). Additionally, there is no generally accepted definition of family firms in the literature, particularly in empirically-oriented studies and in practice. For the purpose of this study, it is assumed that a family business is one in which the family is influenced by three of its components: ownership, management and control (Handler, 1989, pp. 257-276; Shanker \& Astrachan, 1996, pp. 107-123; Sharma, 2004, pp. 1-36). The operationalisation of this influence is reflected in the substantial family influence index (SFI) proposed by Klein (2000, p. 17). This index assumes that in a family enterprise, the family owns at least one share and the sum of weighted family shares in ownership, management and control is not less than one (Klein, 2000, pp. 157-173).

From research conducted around the world, many different characteristics have been identified, some of which differ between family and non-family firms. These differences occur because a family enterprise consists of three systems: family, ownership and enterprise (Gersick, Davis, Hampton, \& Lansberg, 1997, p. 5). In a family enterprise, in addition to the typical financial goals related to the company's profit and value, there are also non-financial goals (Astrachan \& Zellweger, 2008, pp. 83-108; Chrisman, Chua, Pearson, \& Barnett, 2012, pp. 267-293).

However, while researchers agree on the existence of differences in the objectives of family enterprises in relation to non-family enterprises, there is no consensus on the priority of the family business for financial or non-financial purposes (Jaskiewicz \& Klein, 2007, pp. 1080-1089; Achleitner, Bock, Braun, Schraml, \& Welter, 2010, pp. 227-258). Family enterprises face permanent challenges due to the disparate understanding of family rationality and the rationality of their enterprise (Simon, 2012). The effectiveness of a family enterprise should ensure the achievement of the family's goals without disrupting the rational foundations of running a business (Märk, Kraus, \& Peters, 2010, pp. 31-59).

One understandable characteristic is that family firms would like to pass their businesses to their heirs (Anderson \& Reeb, 2003; Andres, 2008; Blanco-Mazagatos, Cuevedo-Puente, \& Castrillo, 2007; Mishra \& McConaughy, 1999). While it 
is clear that conflicts within the family or between some families are possible, this orientation is the basis for a typically long-term orientation in management decisions (James, 1999; McConaughy, Matthews, \& Fialko, 2001; Ward, 1997). This means that striving to ensure the long-term survival of the company is more important than increasing its value (Anderson, Mansi, \& Reeb, 2003, pp. 263-285). The processes of succession and entry into the enterprise by the next generation of owners has caused the emergence of new groups of stakeholders, changing the hierarchy of goals and increasing the professionalisation of management (Koładkiewicz, 2015, p. 138). Succession leads to a preference for the company's economic goals and a reduced importance on family goals (Jaskiewicz \& Klein, 2007).

Furthermore, families want to remain in control of their firms (Chrisman et al., 2003; Gómez-Mejía, Takács Haynes, Nuñez-Nickel, Jacobson, \& Mojano-Fuentes, 2007) meaning that independence from other partners is also an important goal. Some influences can be highlighted for this central goal. For example, family firms do not like banks and equity investors from outside the family to have too much influence (see relationship banking by Pernsteiner \& Węcławski, 2016). Family members would use their firm's finances to earn a (personal) reputation (Ampenberger, Schmid, Achleitner, \& Kaserer, 2013; Dyer \& Whetten, 2006; Ellul, 2009).

From a financial point of view, families tend to have undiversified portfolios (Andreson \& Reeb, 2003; Dreux, 1990) despite often being very rich. We can see two interesting consequences of this here. First, this situation will lead to riskaverse behaviour in management (Hiebl, 2013), no differences in risk management to non-family firms (Dick \& Pernsteiner, 2015) and, for example, a lower level of investment and a tendency towards a more conservative financial policy, often within the capital structure (Pernsteiner \& Dick, 2013).

Second, and this is very much in line with these arguments, there are strong interests in the firm's survival (Ang, 1992). Family firms have a lower level of value-creating management concepts, such as value-based management, than non-family firms (Dick \& Pernsteiner, 2015).

The subject literature indicates the impact of the size of a family enterprise on its business objectives. In young and small enterprises, family goals such as the attitude towards survival, creating jobs for the family and socio-emotional values (socio-emotional wealth) are often more important than rational economic goals (Berrone, Cruz, \& Gómez-Mejía, 2012; Zellweger \& Astrachan, 2008, pp. 347-363). Along with an increase in the size of the enterprise, the activity is complicated and requires more professionalisation, along with the employment of external managers. This leads to the weakening of the importance of the family's goals and the gradual domination of purely economic goals (Olson, Zuiker, Danes, Stafford, Heck, \& Duncan, 2003).

The open nature of modern economies means that a large number of enterprises are included in international exchanges. Internationalisation is treated as one of the aspects of a company's development strategy (Claver, Rienda, \& Quer, 2007, p. 457). This also applies to small and medium-sized enterprises, which are often 
family enterprises. However, there is no consensus among researchers regarding whether family enterprises are more internationalised than non-family enterprises, or vice versa. The results of some surveys indicate that family businesses participate to a lesser extent in international trade, which is particularly reflected in the lower share of foreign turnover within the total turnover (Fernandez \& Nieto, 2005, p. 81). This is the result of the influence of the family members who are managing the family business and are less inclined to undertake foreign activities than external managers from non-family enterprises (Zahra, 2003, p. 501). The concern of the owners about the loss of control over the enterprise (Gallo \& Pont, 1996, p. 48) and the unwillingness to borrow from outside the bank, which is often necessary for foreign operations (Graves \& Thomas, 2008, p. 161), also have a negative impact on the level of internationalisation of family businesses. Other studies, however, raise arguments which indicate that the characteristics of family enterprises positively affect the level of their internationalisation, such as long-term orientation and the concentration of power in the hands of the owners, if they are focused on greater internationalisation (Klein, 2008, p. 14).

The contribution of this paper to the research and literature comes from the point of view of the authors in two fields. Our focus is on Poland, a large Eastern European country with a relatively brief history as a market economy compared with other Western European countries. As a consequence, Poland has a relatively small private sector and there are fewer large and well-established family firms than in the Western European counterparts (Family Business Yearbook, 2014, p. 21). The historical differences in the timeline of the market economy or cultural differences between Western European countries and Poland could be one of the reasons for different orientation of Polish family firms. We use an empirical methodology for this study based on questionnaire-based interviews (computer-assisted telephone interview (CATI) and computer-assisted web interview (CAWI) techniques) conducted on a nationwide scale. The answers given by managers were part of a large finance-oriented questionnaire. The analysis of the collected empirical data is based on the analysis of the structure of the population and the analysis of interdependencies. The results for family and non-family enterprises are compared and the significance of the differences are also analysed.

\section{Data and sample description}

The questionnaire was conducted in the third quarter of 2014 using a random sample of 758 Polish firms that employed more than 49 people. Small enterprises were not included in this sample because they often have no clearly focused goals or strategies. Using the SFI (Klein, 2010) as a concept, which defines a family firm based on the stake of the family in the firm's equity and the percentage of family members in the management and on the supervisory board, we identified 396 firms that were also 
family businesses. There were also a small number of listed companies within this sample. Nearly half of the enterprises employed 50-99 people and were considered to be medium-sized firms. The large companies represented only $6 \%$ of the research sample.

More than $75 \%$ of the family firms were established between 1989 (the beginning of Poland's market economy) and 2003, with only 14\% being established before 1989 . Therefore, it was logical to state that more than two-thirds of the owners were from the first generation, one-third from the second generation, and almost no owners from the third or subsequent generations. The average age of the family firms was $21 ; 22$ for non-family firms.

Both family and non-family firms were similar in their sector structure. The dominant sector of the family firms was manufacturing, which represents $57 \%$, with construction at $14 \%$, the service sector at $10 \%$ and trade at $6 \%$.

A total of $18 \%$ of family enterprises created revenues up to PLN 8 million, $56 \%$ created revenues from PLN 8 to 40 million, and the remaining firms generated more than PLN 40 million. The turnover structure of non-family enterprises was similar and there were slightly fewer companies with the lowest turnover (up to PLN 8 million) and more with the largest turnover (more than PLN 40 million). Therefore, although medium-sized companies were predominant in the sample, they were mostly small enterprises in terms of turnover value.

The structure of revenues of non-family enterprises was also very similar. We found that $61 \%$ of the family firms had a stronger engagement in exports than their non-family firm counterparts ( $43 \%$ ). An analogous difference was related to the share in imports, in which $66 \%$ of family businesses and $56 \%$ of non-family businesses were involved. Other forms of internationalisation (foreign branches, joint ventures, franchise) occurred sporadically.

\section{Research design and first results}

As mentioned above in the literature, there is no doubt that the long-term orientation in management decisions is typical for family firms. Therefore, we will argue that the goal of "long-term orientation" will be more important for family firms than for non-family firms.

Similarly, for Goal 2 in our list concerning "independence to others" (see Table 1), the literature clearly shows that families like to control their firms and do not, therefore, like to be influenced by shareholders and stakeholders from outside the family. It is very difficult to split the different groups of stakeholders in a questionnaire; consequently, for family firms, in general, the goal of "independence to others" is more important than for the non-family group.

The third point is "risk reduction". The majority of the literature posits that family firms tend to exhibit risk-averse behaviour because they tend to have undiversified portfolios. Long-term orientation and the tendency to reduce risks more than other 
owner-groups are activities that can mitigate the disadvantages of these undiversified portfolios. Accordingly, we argue that family firms are more oriented towards risk reduction than non-family firms.

The influence of the family in the firm will lead to special structures, goals and behaviour patterns (Habbershon \& Williams, 1999), as well as a high engagement of the family members in the firm. Therefore, it could be stated that family firms will achieve high growth rates in general, perhaps more so than other types of firms. The most important goal of a firm is to create value. The long-term orientation of a family firm is combined with the goal of "value creation" to form this long-term orientation. For family firms, long-term value creation will be more important than for non-family firms.

For Goals 6 to 9 (see Table 1), the background is more oriented towards the personal position of the members of the family and their relationships to the firm. Between family and firm, there is an emotional bond; thus, family firms prefer to create jobs more than their non-family counterparts. Long-term orientation, in combination with a stronger personal binding to the other stakeholders, leads to a stronger, long-term oriented relationship with others. Despite all these aspects, the family owners aspire to a high standard of living (Goal 8). From the roots of the emotional bonding to the firm stems the goal of "short-term profit maximation". We posit that this goal is more important to non-family firms.

We presented these nine goals to the firm managers and asked them to rate them as either very important, important, less important, or not relevant (not important) to the firm. The differences between family firms (FF) and non-family firms (NFF) are detailed in Table 1.

Table 1. Goals of Polish family firms and non-family firms

\begin{tabular}{|c|c|c|c|c|c|c|c|c|}
\hline \multirow{3}{*}{ Goal } & \multicolumn{8}{|c|}{ Importance for firms (in \%) } \\
\hline & \multicolumn{2}{|c|}{ Very important } & \multicolumn{2}{|c|}{ Important } & \multicolumn{2}{|c|}{ Less important } & \multicolumn{2}{|c|}{ Not important } \\
\hline & FF & NFF & FF & NFF & FF & NFF & FF & NFF \\
\hline 1. Long-term orientation & 94.1 & 92.7 & 3.1 & 4.6 & 0.8 & 0.9 & 2.0 & 1.8 \\
\hline 2. Independence from others & 83.0 & 65.9 & 8.9 & 10.7 & 4.0 & 11.1 & 4.1 & 12.3 \\
\hline 3. Risk reduction & 77.9 & 76.1 & 17.0 & 16.9 & 2.1 & 4.5 & 3.0 & 2.5 \\
\hline 4. High growth rates & 76.0 & 66.6 & 20.3 & 22.1 & 2.2 & 6.4 & 1.5 & 4.9 \\
\hline 5. Long-term value creation & 73.0 & 62.2 & 18.7 & 22.9 & 4.5 & 9.1 & 3.8 & 5.8 \\
\hline 6. Job creation & 63.8 & 57.9 & 24.2 & 28.2 & 9.7 & 11.1 & 2.3 & 2.8 \\
\hline $\begin{array}{l}\text { 7. Strong, long-term relationships } \\
\text { with others }\end{array}$ & 61.6 & 59.5 & 22.5 & 21.2 & 11.6 & 11.3 & 4.3 & 8.0 \\
\hline 8. High standard of living & 57.5 & 26.6 & 23.8 & 22.0 & 12.6 & 17.0 & 6.1 & 34.4 \\
\hline 9. Short-term profit maximation & 43.4 & 37.8 & 28.2 & 29.9 & 24.3 & 24.1 & 4.1 & 8.2 \\
\hline
\end{tabular}

$\mathrm{FF}$ - family firms, NFF - non-family firms

Source: Authors' own study.

Table 1 shows that more than $75 \%$ of family firms saw long-term orientation, independence, risk reduction and high growth rates as being very important goals, with long-term value creation being seen as almost as important. Furthermore, it is 
also clear that there are differences between family firms and non-family firms. In the four goals mentioned above, family firms have higher percentages of consent than non-family firms. In general, family firms have a stronger commitment to these goals than non-family firms.

We would like to add three additional aspects to the discussion: the age of the firm, the level of internationalisation and the size of the firm. The age of the firm is an indicator of both organisational stability and perhaps the expertise in business fields. It is also a sign of openness and perhaps the ability to take greater risks. Size is also an indicator for diversification. We divide each aspect into further subcategories:

1. Age of the firm: Established 2004-2014, 1989-2003 or before 1989.

2. Level of internationalisation: Turnover is more than $50 \%$ in Poland or abroad.

3. Size: Turnover up to PLN 8 million; PLN 8-40 million; PLN 40-200 million, or more than PLN 200 million.

According to our arguments shown above and the results of the descriptive statistics (Table 1), we can fix our hypotheses, thus:

1. Family firms are more oriented towards a long-term view in management.

2. For family firms, independence from other partners is more important than for non-family firms.

3. Risk reduction in day-to-day business is more important for family firms than for non-family firms.

Table 2 shows the differences between family firms and non-family firms for the nine goals. The differentiation is for age, internationalisation and size. The significances are marked, and we used the two-tailed test.

Table 2. Family firms and non-family firms differentiated in categories (in \%)

\begin{tabular}{|c|c|c|c|c|c|c|c|c|c|c|}
\hline \multirow[t]{2}{*}{ Firms } & \multirow[t]{2}{*}{ Total } & \multicolumn{3}{|c|}{ Age } & \multicolumn{2}{|c|}{$\begin{array}{c}\text { Internationali- } \\
\text { sation }\end{array}$} & \multicolumn{4}{|c|}{ Turnover } \\
\hline & & 1 & 2 & 3 & 1 & 2 & 1 & 2 & 3 & 4 \\
\hline \multicolumn{11}{|c|}{ 1. Long-term orientation } \\
\hline FF & 96.1 & 100.0 & 95.5 & 96.2 & 95.2 & 100.0 & 97.2 & 94.0 & 99.0 & 100.0 \\
\hline NFF & 94.4 & 90.6 & 95.3 & 88.0 & 94.3 & 93.6 & 88.7 & 96.3 & 94.0 & 100.0 \\
\hline Sig. & & $* *$ & & & & $* *$ & $*$ & & $*$ & \\
\hline \multicolumn{11}{|c|}{ 2. Independence from others } \\
\hline FF & 86.5 & 89.5 & 87.1 & 80.8 & 86.0 & 89.2 & 87.0 & 86.4 & 86.7 & 84.6 \\
\hline NFF & 75.2 & 83.3 & 73.7 & 81.8 & 76.3 & 68.9 & 74.5 & 78.7 & 71.8 & 58.3 \\
\hline Sig. & $* * *$ & & $* * *$ & & $* * *$ & $* *$ & $*$ & $*$ & $* *$ & \\
\hline \multicolumn{11}{|c|}{ 3. Risk reduction } \\
\hline $\mathrm{FF}$ & 80.2 & 75.0 & 80.4 & 81.8 & 79.8 & 86.8 & 81.7 & 79.1 & 80.4 & 86.7 \\
\hline NFF & 78.7 & 81.3 & 77.4 & 88.0 & 80.1 & 72.9 & 78.3 & 79.2 & 77.4 & 83.3 \\
\hline Sig. & & & & & & $*$ & & & & \\
\hline \multicolumn{11}{|c|}{ 4. High growth rates } \\
\hline $\mathrm{FF}$ & 77.1 & 79.5 & 75.3 & 83.3 & 76.8 & 78.8 & 81.1 & 72.0 & 83.0 & 86.7 \\
\hline NFF & 70.0 & 81.3 & 69.9 & 58.3 & 69.2 & 72.9 & 57.9 & 71.3 & 71.4 & 100.0 \\
\hline Sig. & $* *$ & & & $* *$ & $*$ & & $* * *$ & & $*$ & $*$ \\
\hline
\end{tabular}


Pobrane z czasopisma Annales H - Oeconomia http://oeconomia.annales.umcs.pl

Data: 26/04/2023 11:47:49

JERZY WĘCŁAWSKI, HELMUT PERNSTEINER

\begin{tabular}{|c|c|c|c|c|c|c|c|c|c|c|}
\hline \multirow{2}{*}{ Firms } & \multirow{2}{*}{ Total } & \multicolumn{3}{|c|}{ Age } & \multicolumn{2}{|c|}{$\begin{array}{l}\text { Internationali- } \\
\text { sation }\end{array}$} & \multicolumn{4}{|c|}{ Turnover } \\
\hline & & 1 & 2 & 3 & 1 & 2 & 1 & 2 & 3 & 4 \\
\hline \multicolumn{11}{|c|}{ 5. Long-term value creation } \\
\hline FF & 75.9 & 66.7 & 76.5 & 79.2 & 73.7 & 86.8 & 74.3 & 70.5 & 85.6 & 92.9 \\
\hline NFF & 66.0 & 68.8 & 66.5 & 57.1 & 64.8 & 67.4 & 59.3 & 63.0 & 72.6 & 91.7 \\
\hline Sig. & $* * *$ & & $* *$ & * & ** & ** & * & & ** & \\
\hline \multicolumn{11}{|c|}{ 6. Job creation } \\
\hline FF & 65.3 & 71.1 & 62.6 & 74.5 & 64.0 & 73.1 & 75.3 & 63.1 & 63.9 & 53.3 \\
\hline NFF & 59.6 & 57.6 & 58.6 & 64.0 & 60.1 & 58.7 & 54.1 & 56.5 & 65.0 & 91.7 \\
\hline Sig. & & & & & & & $* *$ & & & ** \\
\hline \multicolumn{11}{|c|}{ 7. Strong, long-term relationships with others } \\
\hline FF & 64.3 & 52.6 & 64.4 & 71.2 & 65.4 & 59.7 & 73.6 & 57.6 & 70.2 & 71.4 \\
\hline NFF & 64.5 & 54.5 & 64.2 & 76.2 & 67.0 & 56.8 & 66.7 & 65.8 & 58.2 & 81.8 \\
\hline Sig. & & & & & & & & & * & \\
\hline \multicolumn{11}{|c|}{ 8. High living standards } \\
\hline FF & 61.2 & 66.7 & 59.6 & 66.7 & 60.0 & 65.1 & 61.6 & 63.1 & 58.9 & 46.2 \\
\hline NFF & 40.6 & 39.1 & 41.3 & 28.6 & 42.8 & 34.3 & 38.9 & 40.0 & 38.1 & 75.0 \\
\hline Sig. & $* * *$ & ** & $* * *$ & $* *$ & $* * *$ & $* * *$ & ** & $* * *$ & ** & \\
\hline \multicolumn{11}{|c|}{ 9. Short-term profit maximation } \\
\hline FF & 45.2 & 48.7 & 43.6 & 49.1 & 46.6 & 42.4 & 58.3 & 41.5 & 40.6 & 60.0 \\
\hline NFF & 41.2 & 43.8 & 40.9 & 36.4 & 40.6 & 38.3 & 40.0 & 38.0 & 50.0 & 25.0 \\
\hline Sig. & & & & & & & ** & & & ** \\
\hline
\end{tabular}

FF - family firms, NFF - non-family firms

Age: 1 - 2004-2014; 2 - 1989-2003, 3 - before 1989; Internationalisation: More than 50 turnovers (1 - Poland, 2 -abroad). Turnover: 1 - up to PLN 8 million; 2 - PLN 8-40 million; 3 - PLN 41-200 million; 4 - more than PLN 200 million.

Statistical significance: $* p<0.1 ; * * p<0.05 ; * * * p<0.01$, respectively.

Source: Authors' own study.

\section{Results and discussion}

In general, we cannot find significance for the stronger "long-term orientation" of family firms. However, we observe that the younger and more export-oriented family firms seem to be more long-term oriented. The younger family firms are primarily in the first generation and are more focused on a long-term orientation than firms in the second or third generation, which had generation transfers. Younger family firms are aware of the multitudinous risks, meaning that their will to survive is very strong and they have a solid focus on a long-term orientation. Export-oriented family firms take more risks and often invest more financial resources in internationalisation strategies. Therefore, they have a stronger long-term perspective. In light of these results, Hypothesis 1 can only be partially accepted.

"Independence from others" gives clearer results, as the difference between family and non-family firms is significant. According to the literature, we can confirm that this goal is very important for family firms. In fact, it is strongly significant for the large group of middle-aged family firms and for companies that are more oriented in their business activities in Poland. Therefore, we can accept Hypothesis 2. 
Likewise, if we look to the goal of "risk reduction", we can see a clear picture. There is no significant difference between family firms and their non-family counterparts in general and in all subcategories. Our results align with Dick and Pernsteiner's (2015) results for Austrian and German family firms. Professionalism is the same for family and non-family firms; therefore, both types of firms use the same instruments for risk management. A questionnaire may not also be as precise as quantitative data; managers may also respond that they have risks under their control due to overconfidence in their management expertise. In summary, we cannot say that family firms are more risk-averse, and therefore we cannot accept Hypothesis 3.

Beyond these hypotheses, we can look for further results. There is a clear difference between family and non-family firms regarding the goal of achieving "high living standards". This goal pertains more to individuals than corporations, and therefore we would not make further arguments. In general, family firms are more oriented towards the goals of "long-term value creation" and "high growth rates". Therefore, it is not possible to argue that family firms are less professional than non-family firms. The long-term value orientation is present in nearly all subcategories. The goal of high growth rates is greater for older and smaller firms; they are more interested in coming "back" to higher growth rates. In general, both goals show us the high levels of engagement and the strong bonds that exist between the families and their firms. They will work together to strongly pursue their goals.

"Job creation", "strong, long-term relationships with others", and "short-term profit maximation" are only significant in a few subcategories; thus, we are unable to provide a strong correlation. "Independence from others" (the "independence" argument), "high growth rates" and "long-term value creation" are goals in which family firms are more strongly oriented than non-family firms.

Regarding limitations, since the data is specific to Poland and because of cultural and economic differences, we cannot generalise these results. In addition, a significant number of Polish family enterprises are still in the hands of the first generation, namely the founder or the founder's family. This may result in family goals being a significant part of the ethos of the business.

\section{Acknowledgements}

The authors are very grateful for the financial aid given by the Polish National Science Centre (NCN Project No. 2012/07/B/HS4/00455, "Corporate governance ownership structure and other financial issues of family business in Poland and Austria - a comparative analysis") in order to realize this research. 


\section{References}

Achleitner, A.-K., Bock, C., Braun, R., Schraml, S., \& Welter, J. (2010). Zielstrukturen in Familienunternehmen: Empirische Hinweise auf die Beziehung zwischen Unternehmens- und Familienzielen. Zeitschrift für KMU und Entrepreneurship, 58(3), 227-258. doi:10.3790/zfke.58.3.227

Aldrich, H.E., \& Cliff, J.E. (2003). The pervasive effects of family on entrepreneurship: Toward a family embeddedness perspective. Journal of Business Venturing, 18(5), 573-596.

doi:10.1016/S0883-9026(03)00011-9

Ampenberger, M., Schmid, T., Achleitner, A.-K., \& Kaserer, C. (2013). Capital structure decisions in family firms: Empirical evidence from a bank-based economy. Review of Managerial Science, 7(3), 247-275.

Anderson, R.C., Mansi, S.A., \& Reeb, D.M. (2003). Founding family ownership and the agency cost of debt. Journal of Financial Economics, 68(2). doi:10.2139/ssrn.303864

Anderson, R.C., \& Reeb, D.M. (2003). Founding-family ownership and firm performance: Evidence from the S\&P 500. The Journal of Finance, 58(3), 1301-1328.

Andres, C. (2008). Large shareholders and firm performance - an empirical examination of founding-family ownership. Journal of Corporate Finance, 14(4), 431-445. doi:10.1016/j.jcorpfin.2008.05.003

Ang, J.S. (1992). On the theory of finance for privately held firms. Journal of Small Business Finance, 1(3), 185-203.

Astrachan, J.H., \& Zellweger, T. (2008). Die Performance von Familienunternehmen: Literaturübersicht und Orientierungshilfe für künftige Forschungsarbeiten. Zeitschrift für KMU und Entrepreneurship, 56(1-2). doi:10.3790/zfke.56.1_2.83

Berrone, P., Cruz, C.C., \& Gómez-Mejía, L.R. (2012). Socioemotional wealth in family firms: A review and agenda for future research. Family Business Review, 25(3), 258-279. doi:10.1177/0894486511435355

Blanco-Mazagatos, V., Cuevedo-Puente, E., \& Castrillo, L.A. (2007). The trade-off between financial resources and agency costs in the family business: An exploratory study. Family Business Review, 20(3), 199-213. doi:10.1111/j.1741-6248.2007.00095.x

Chrisman, J., Chua, J.H., \& Litz, R. (2003). A unified systems perspective of family firm performance: An extension and integration. Journal of Business Venturing, 18(4), 467-472. doi:10.1016/S08839026(03)00055-7

Chrisman, J.J., Chua, J.H., Pearson, A.W., \& Barnett, T. (2012). Family involvement, family influence and family-centered non-economic goals in small firms. Entrepreneurship Theory and Practice, 36(2). doi:10.1111/j.1540-6520.2010.00407.x

Claver, E., Rienda, L., \& Quer, D. (2007). Family firms' risk perception: empirical evidence on the internationalisation process. Journal of Small Business and Enterprise Development, 15(3), 457-471. doi:10.1108/14626000810892283

Dick, M., \& Pernsteiner, H. (2015). The impact of family influence on the financial sophistication of firms. European Journal of Management, 15(2). doi:10.18374/EJM-15-2.2

Dreux, D.R. (1990). Financing family business: alternatives to selling out or going public. Family Business Review, 3(3). doi:10.1111/j.1741-6248.1990.00225.x

Dyer, W.G., \& Whetten, D.A. (2006). Family firms and social responsibility: Preliminary evidence from the S\&P 500. Entrepreneurship Theory and Practice, 30(6). doi:10.1111/j.1540-6520.2006.00151.x

Ellul, A. (2009). Control Motivations and Capital Structure Decisions, Working Paper, Kelley School of Business, IN University, Bloomington.

Family Business Yearbook. (2014). Ernst \& Young Global Limited.

Fernandez, Z., \& Nieto, M.J. (2005). Internationalization strategy of small and medium-sized family businesses: some influential factors. Family Business Review, 18(1). doi:10.1111/j.1741-6248.2005.00031.x

Gallo, M.A., \& Pont, C.G. (1996). Important factors in family business internationalization. Family Business Review, 9(1).

Gersick, K.E., Davis, J.A., Hampton, M., \& Lansberg, I. (1997). Generation to Generation Life Cycles of the Family Business. Boston: Harvard Business School Press. 
Gómez-Mejía, L.R., Takács Haynes, K., Nuñez-Nickel, M., Jacobson, K.J.L., \& Mojano-Fuentes, J. (2007). Socioemotional wealth and business risks in family-controlled firms: Evidence from Spanish olive oil mills. Administrative Science Quarterly, 52(1), 106-137.

Graves, C., \& Thomas, J. (2008). Determinants of the internationalization pathways of family firms: An examination of family influence. Family Business Review, 21(2). doi:10.1111/j.1741-6248.2008.00119.x

Habbershon, T.G., \& Williams, M.L. (1999). A resource-based framework for assessing the strategic advantages of family firms. Family Business Review, 12(1). doi:10.1111/j.1741-6248.1999.00001.x

Handler, W.C. (1989). Methodological issues and considerations in studying family businesses. Family Business Review, 2(3). doi:10.1111/j.1741-6248.1989.00257.x

Hiebl, M.R.W. (2013). Risk aversion in family firms: what do we really know? Journal of Risk Finance, 14(1), 49-70.

James, H.S. (1999). Owner as manager. Extended horizons and the family firm. International Journal of the Economics of Business, 6(1), 41-55. doi:10.1080/13571519984304

Jaskiewicz, P., \& Klein, S.B. (2007). The impact of goal alignment on board composition and board size in family businesses. Journal of Business Research, 60(10), 1080-1089.

Jeżak, J. (2016). Rozwój przedsiębiorczości rodzinnej w Polsce na tle tendencji światowych. Przegląd Organizacji, 4.

Klein, S.B. (2000). Family businesses in Germany: Significance and structure. Family Business Review, 13(3), 157-181.

Klein, S.B. (2008). Internationale Familienunternehmen - Definition und Selbstbild. In: C. Rödl, W. Scheffler, M. Winter (Hrsg.), Internationale Familienunternehmen. München: Verlag C.H. Beck.

Klein, S.B. (2010). Familienunternehmen. Lohmar-Köln: Verlag Eul.

Koładkiewicz, I. (2015). System nadzoru w firmie rodzinnej. Doświadczenia polskie i światowe. Warszawa: Poltext.

Märk, S., Kraus, S., \& Peters, M. (2010). Der Einfluss der Familie auf den Unternehmer: Eine qualitativempirische Untersuchung von Familienunternehmen auf Basis der Stewardship-Theorie. Zeitschrift für KMU und Entrepreneurship, 58(1). doi:10.3790/zfke.58.1.31

McConaughy, D.L., Matthews, C.H., \& Fialko, A.S. (2001). Founding Family Controlled Firms: Performance, Risk and Value. Journal of Small Business Management, 39(1), 31-49. doi:10.1111/0447-2778.00004

Mishra, C.S., \& McConaughy, D.L. (1999). Founding family control and capital structure: The risk of loss of control and the aversion to debt. Entrepreneurship Theory and Practice, 23(4). doi:10.1177/104225879902300404

Olson, P.D., Zuiker, V.S., Danes, S.M., Stafford, K., Heck, R.K.Z., \& Duncan, K.A. (2003). The impact of the family and the business on family business sustainability. Journal of Business Venturing, 18(5), 639-666. doi:10.1016/S0883-9026(03)00014-4

Pernsteiner, H., \& Dick, M. (2013). The capital structure and the dividend policy of family firms. Annales Universitatis Mariae Curie-Skłodowska, Sectio H-Oeconomia, 47(4).

Pernsteiner, H., \& Węcławski, J. (2016). How do Polish non-listed family firms engage in strong relationship banking? In: M. Asal (ed.), Contemporary Problems in Corporate Governance. Rapport Högskolan Väst, No. 3. Sweden.

Shanker, M.C., Astrachan, J.H. (1996). Myths and realities. Family businesses' contribution to the US economy - a framework for assessing family business statistics. Family Business Review, 9(2), 107-123.

Sharma, P. (2004). An Overview of the Field of Family Business Studies. Current Status and Directions for the Future. Family Business Review, 17(1), 1-36. doi:10.1111/j.1741-6248.2004.00001.x

Simon, F.B. (2012). Einführung in die Theorie des Familienunternehmens. Heidelberg: Carl-Auer Verlag. Ward, J.L. (1997). Growing the family business: Special challenges and best practices. Family Business Review, 10(4), 323-337. doi:10.1111/j.1741-6248.1997.00323.x 
Pobrane z czasopisma Annales H - Oeconomia http://oeconomia.annales.umcs.pl Data: 26/04/2023 11:47:49

Zahra, S.A. (2003). International expansion of U.S. manufacturing family businesses: The effect of ownership and involvement. Journal of Business Venturing, 18(4), 495-512. doi:10.1016/S0883-9026(03)00057-0

Zellweger, T.M., \& Astrachan, J.H. (2008). On the emotional value of owning a firm. Family Business Review, 2l(4). doi:10.1177/08944865080210040106 